\title{
NARRATING BLASPHEMY: (DE)CONSTRUCTING THE SATANIC
}

\author{
Trajanka Kortova \\ University of Avignon, France \\ tkortova@gmail.com
}

This paper focuses on the representations of the Devil/Satan in Salman Rushdie's The Satanic Verses, José Saramago's The Gospel According to Jesus Christ and Mikhail Bulgakov's The Master and Margarita in order to examine the roles that the satanic principle plays within the unorthodox and even openly blasphemic architectonics of novels which function as profane rewritings of the religious tradition and sacred scriptures of Christianity and/or Islam. Destabilizing the orthodox imagology of Satan as ethically evil and God's 'Adversary', the chosen novels reinscribe the satanic as an expression of the 'impure' and differential aspect of identity, language and knowledge. In positing a satanically diversified ontology, ethics and epistemology, Rushdie's, Saramago's and Bulgakov's novels appropriate the satanic as an essentially artistic or literary principle aimed against the monologic and suppressive discourses that conform to the oppressive logic of the One.

Keywords: Satan/satanic, difference, logos, ontology, hermeneutics 


\section{РАСКАЖУВАҢЕ БОГОХУЛСТВО: (ДЕ)КОНСТРУИРАњЕ НА САТАНСКОТО}

Трајанка Кортова

Универзитет во Авињон, Франција

tkortova@gmail.com

Овој есеј ги разгледува начините на кои е претставен ѓаволот/сатаната во

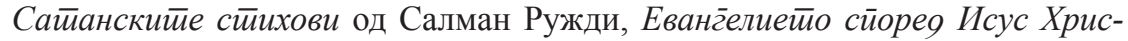

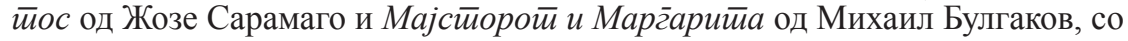
цел да ги испита улогите што ги игра сатанскиот принцип во неортодоксната и дури отворено богохулна архитектоника на романи, кои функционираат како световни пренапишувања на религиската традиција и светите писма на христијанството и/или исламот. Дестабилизирајќи ја ортодоксната имагологија за сатаната како етички зол и Божји противник, избраните романи го впишуваат сатанското како израз на „нечистиот“ и диференцијален аспект на идентитетот, јазикот и на познанието. Со тоа што воспоставуваат сатански разнолика онтологија, етика и епистемологија, романите на Ружди, Сарамаго и на Булгаков го присвојуваат сатанското како, во суштина, уметнички или книжевен принцип, насочен против монолошките и потчинувачки дискурси кои се повинуваат на опресивната логика на Едното.

Клучни зборови: сатана/сатанско, разликовност, логос, онтологија, херменевтика 


\section{The Satanic nature of logos}

Leonard W. Levy succinctly defines blasphemy as "speaking evil of sacred matters" (Levy 1995: 3); as the subtitle of his book has it, it is specifically a "verbal offence against the sacred". As a particular, i.e. derogatory, use of language against God and the sacred, blasphemy stands opposed to the divine logos, which in Christianity has a direct embodiment as one of the three aspects of God - the beginning of the Gospel according to St. John refers to Jesus as "the Word" of God made flesh in the person of the Christ, for "In the beginning was the Word, and the Word was with God, and the Word was God" (John, 1:1). As a personification of the Logos, Jesus represents the creationary aspect of God, who by the power of his word creates the world into existence: "And God said, Let there be light: and there was light" (Genesis, 1:3). In Islam, however, it is the holy book that has this divine status: "the Qur' an is the Uncreated Word of God - an intrinsic part, as it were, of the Divine Essence, [...] a part of the Divine Logos" (Ruthven 1991: 8). In Salman Rushdie's The Satanic Verses, the Qur'an is destabilized at its source by insinuating the satanic into its divine essence, which introduces an element of difference. As the divine Book, which gives prescriptive judgments and aspires to immutability, finality and universality, allows its eternity to be inscribed in history, it opens itself up to the contingencies of the mutable and the relative. The effect of the satanic verses is to undermine the authority of divine revelation by doubling and therefore diversifying its source. Satan's very appearance in the biblical narrative introduces

difference into a universe that, according to the biblical narrative, was created to be unified. For example, while God created the universe and "everything he had made" to be "very good" (Gen. 1:31), Satan explicitly introduces a concept of difference, namely "good and evil" (Gen. 3:5), implying the possibility that not "everything" was "very good," and thus, questioning the truth of God's word. Satan's use of words therefore dismisses truth and divine authority as knowable categories of interpretation (Sauter 2017: 116).

Etymologically, his name means "Adversary" in Hebrew and as such he can be conceived of not embodying a metaphysical principle, but playing an oppositional and dissenting role, which is Rushdie's esthetic philosophy behind this novel. He does this by relying on his oratorical mastery at proffering alternative interpretations of scriptural messages and exposing the differential, ambiguous and inconstant nature of language. Significantly, his intervention into a text inevitably articulates an already existing problem - in Goethe's Faust, to face Faust with the problem of language after the latter has stumbled upon a difficulty in the translation of the Bible (specifically, the opening of the Gospel according to St. John, "In the beginning was the Word"), and in Rushdie's novel to express Mahound's already existing uncertainty regarding the source of the revelation he preaches and his role therein - is he merely the messenger bearing Allah's words or actually their source? 
The satanic verses episode in the novel is a novelistic reinscription of an incident in the history of Islam when Muhammad was misled by the devil, masquerading as the angel Gibreel, to allow the worship of three pagan goddesses - Al-Lat, Uzza and Manat - alongside that of Allah; when he realized his mistake, he abrogated the verses. The worship of the goddesses is suggested to Mahound purely as a political ploy and he allows it to gain more followers; subsequently, the relevant verses are produced, but in such an ambiguous way that it is impossible to determine whether the archangel willingly says them or Mahound forces them out of him; lastly, Mahound proclaims them as satanic rather than divine and abrogates them, with Gibreel helplessly exclaiming that "it was me, baba, both times", which means that the revelation is simultaneously human, divine and satanic in its source and nature, with Mahound, Gibreel and Satan as its joint originators.

Ever since Satan's eloquent persuasion of Eve to disobey God, he has been primarily conceived as a master of the Word, a skilled orator who insinuates himself into the human consciousness and incites human beings to sin against their God with promises of whatever they desire. Every time, the primary motivation that precipitates man's fall - pre- or post-lapsarian - is the thirst for Knowledge, the desire to partake of the Divine Book that is the world. Thus, after Faustus has mastered all of the knowledge of his time, he still desires more of it to "Resolve [him] of all ambiguities" (Marlowe 1604/2001, 1.1.77). Faustus's Good Angel's first exhortation to him is to "lay that damnèd book [on necromancy] aside / And gaze not on it lest it tempt thy soul / And heap God's heavy wrath upon thy head!", which is countered by the Bad Angel's "Go forward Faustus, in that famous art / Wherein all nature's treasure is contained" (ibid 1.1. 67-9 and 71-2). In an already dialogized oral scripture, containing Gibreel's and Shaitan's words, Salman the scribe, like the snake in Eden, speaks with a forked tongue, undermining Mahound's words with the interpolation of his own.

In Rushdie's rendering, therefore, the divine revelation (and, by implication, language itself), is inherently 'corrupted' or containing its difference/alterity in its very essence. In other words, it is suspect because of its uncertain source (it is unclear whether it comes from God or the Devil), the unreliable medium of its transmission (the angel Gibreel is a protean, playful figure of an uncertain ontological status - he is simultaneously a divine and human consciousness, a modern-day Indian actor dreaming he is the archangel and in the process also becoming him), the human recipient of the divine word (Mahound, whom Rushdie represents not by his venerated authentic name but by the one attributed to him by his despising Others, which compromises his status) and the scribe who writes down the revelation revealed to the prophet (Salman deliberately distorts the words relayed to him in order to test Mahound's authenticity).

Bulgakov's novel incorporates three narrative sequences: the love story about the Master and Margarita, the adventures of Satan and his entourage in Stalinist Moscow and the story about Yeshua and Pilate, which is in fact the Master's novel. Here, the divine logos is also portrayed as fallible and satanically impure at its very source (Yeshua/Jesus is horrified by the contents of the 'gospel' about his teachings composed by his only disciple, Matthew Levi), but is nevertheless capable of recovering and representing truth, as the Master's novel shows. The written word is 
represented as a substitute for the loss of the feeling of transcendence that approximates the believer to God - the Master's imagination has proved itself capable of intuiting the collective archetypal springs of humanity and has recreated the origins of the Christian faith as they really happened, for Woland evokes the very same scenes in the form of a hallucination long before he even meets the Master. The satanic principle in the context of the nature of the logos - both divine and profane - is here used as a guarantor of the indestructibility of truly inspired literature, such as that written by the Master. Woland's powerful message to suppressed art is that "manuscripts don't burn" (287), as he tells the Master when the latter fails to produce the manuscript he has burnt in the stove, upon which it promptly appears intact. The God that Bulgakov's novel portrays is an unorthodox, de-Christianized one, as both Yeshua/Jesus and Woland/Satan are represented as his emanations, with the Master, in his role as the archetypal artist, as his privileged chronicler.

The "Gospel according to Jesus Christ" that is Saramago's novel is represented as an apocryphal, historically conscious one and written from a modern perspective, constantly undermining the Bible in order to foreground the suppressed injustices and cruelties and the untold stories that the Gospel's narrator is nevertheless able to glean from what the scriptures actually say. Although separate from the satanic figure of Pastor (in contrast, in Rushdie's novel the narrator can at times be clearly identified with Satan himself, although both are inscribed in the elusive satanic ontology permeating the novel), the narrative voice embraces the satanically transgressive logic that it is God who should be brought before the judgement of mankind so that He may acknowledge and beg forgiveness for His sins rather than the other way round. The narrator reasons that people's sense of sin and guilt is a pointless burden on the human psyche imposed by religion - why would a God-ordained morality punish Joseph for not trying to prevent the massacre when God himself has allowed the crime to happen? If everything that happens on earth is in accordance with God's plan, why is anything our responsibility? Ironically praising God for saving Jesus from the death he allotted to the innocent children of Bethlehem, the narrator recalls all those nameless and unrecorded victims of history who were not given God' grace - "it is true that God compensated Job by repaying him twice as much as He had taken, but what about all those other men in whose name no book has ever been written, men who have been deprived of everything and been given nothing in return, to whom everything was promised but never fulfilled" $(\mathrm{G}, 96)$. An insistent urge to call God to account permeates this 'Gospel', told by an elusive narrator who is Jesus' contemporary and ours, who knows history and from this position casts an ironic glance on New Testament history.

\section{Satanic ontologies}

As the episode of the satanic verses in Rushdie's novel demonstrates, difference is not only the sine qua non of the Word (both oral and written), but also of identity, as the novel posits a satanic ontology whereby identity is multiply (de) constructed. Firstly, each character is, on the one hand, internally differential, non-unitary, ambivalent and contradictory, and on the other, understandable only 
relationally, in terms of the Other, never in isolation, as a result of which the characters within the same diegetic level are differentiated into binary opposites (Gibreel's continuous self is opposed to Saladin's discontinuous self) and/or each other's doubles and hence can be conceptualized as one amalgamated, hybrid subjectivity. Then, on the vertical axis, i.e. between the various narrative levels, each of the protagonists doubles himself in a dreamed-about persona - Gibreel becomes the archangel and Saladin the glass man; Gibreel's dreams even assume such an ontological and narrative force that they function as narrative strands of an equal footing as the "real" plot featuring their dreamer. Such is the potency of his dreams that he is even unsure whether he is an invention of the archangel or vice versa and whether his dreams are the reality within which he himself is the person dreamed about. Finally, each character is internally dialogized by the satanic voice that is not simply the repressed internal Other disrupting the purity of the self, but functions as an externalized metaphysical entity representing the ontological principle of difference and dissent and, to a lesser extent, the ethical principle of evil. Interestingly, this satanic Other can be traced back to the narrator/author himself and as such functions as a metafictional layer of the already multiply layered identity of the characters.

The devil is an embodiment of paradoxes, inconstancy, and, more importantly, the possibility for self-invention. From the fixed, God-given identity as the brightest angel Lucifer (the Angel of Light), through his fall and expulsion from heaven - a fate he shares with Adam and Eve - he acquires the slippery ontology of the unstable identity, one that is $d i$-versified, dia-bolic and antagonistic (the prefixes di-, de- and dis- derive from the Indo-European words for "two", implying division, discord, and other related meanings, results of the Fall (Forsyth 2003: 219)). In fact, he charts a movement from the God-ordained unity and homogeneity to division and heterogeneity - "diabolos', from which "devil" is derived, is the Greek equivalent of the Hebrew 'Satan', meaning "adversary", "opponent". Such is Satan's fluid ontology that according to a Gnostic tradition, his role is usurped by Christ, who becomes the serpent of Genesis, bringer of Gnosis or spiritual knowledge (ibid, 311), and in this role he is comparable to numerous mythological gods or demi-gods who are bringers of knowledge (Thoth, Prometheus, etc.). As he rejects the identity conferred upon him by God, he is the prototype of the self-made man - the man reinventing himself, the man born anew, which is the ideal defended in the novel, while the immutable essence of divine selfhood is the heresy that needs to be sidelined. Both Milton and Rushdie emphasise the satanic ideal of self-fashioned subjectivity, revealing itself in all its anguish, doubts and dilemmas, as opposed to the unquestioned obedience God demands of his creations - Mahound's religion even identifies itself purely as "submission", hence it inherently requires the diversificatory intervention of the satanic. The satanic trajectory, then, implies a movement from subjection to subjectivity and in Rushdie's novel it is verses - satanic and fictional, or better, satanic-fictional - that perform this formative role.

In Saramago's novel, the devil is the one who embodies this differential satanic ontology, as he assumes the traditional characteristics of both God and Jesus and figures largely as a protective fatherly figure, as is evident in the name he gives 
himself - Pastor. Literally and symbolically a pastor tending his flock, he appears several times as a beggar, thereby testing the characters' ethical responsiveness to this despised social category, and from this position serves as the ethical centre of the novel. It is he who first marks Jesus as special and with God remaining largely silent in resolving Jesus' angst, it is Pastor who undertakes to provide spiritual guidance for him by taking him under his protection. His identity remains elusive and is thus inscribed into the characteristically vague satanic ontology - he never reveals who he really is and whether he follows the divine Providence or acts on his own, but the ethics he practices breaks the stereotypical satanic mold. If Rushdie's Satan evacuates ethics of its meaning by being the carrier of ambiguity, plurality and difference in the homogeneous world created by God, Saramago's Pastor provides a clear ethical example for Jesus and, in doing so, unmasks God's own duplicity. By disinterestedly tending his ever-expanding flock of goats and sheep, he is represented as a literal pastor, a fatherly figure who raises his 'children' and expects nothing in return. When Jesus cannot bring himself to sacrifice a lamb at Passover, when Israel's altars burn with the fire of the people's devotion, Pastor encourages Jesus to care for it instead; however, later the lamb is nevertheless sacrificed, as God requires it from Jesus in order to seal their covenant. Pastor promptly banishes him: "You've learned nothing, be gone with you" (199).

In the otherworldly plot of Rushdie's novel, Satan tries to erase God from the memory of the believers and to instill a denigrating attitude towards his adherents, but here he is aware of his impotence to abandon the terms of his 'devil-ness' and instead erodes God's authority by providing a real fatherly example to Jesus, which serves as a counterpoint to God's false one. He openly repudiates a God who demands the sacrifice of his creations and who is ready to let his chosen Son perish on the cross only to bolster his own power - if God were really deserving of the people's love and filial devotion, he tacitly seems to be saying to Jesus, he would care for his children the way I care for my flock.

In a climactic scene Jesus pleads with God to show him the future that his sacrifice will bring, upon which God equivocates and it is Pastor who openly replies that God's church will be built "in order to be truly solid, its foundations will be dug out in flesh, and the bases made from the cement of abnegation, tears, suffering, torment, every conceivable form of death known or as yet unrevealed" (290). Jesus demands further details and God reluctantly provides a bleak view of history in all its incomprehensible horror: the names and horrible deaths of Jesus' followers (beheaded, crucified, stoned, skinned alive, sawn in half, speared to death, burnt at the stake, disemboweled, impaled, drawn and quartered, thrown onto iron spikes, gored or devoured by animals, in "an endless tale of iron and blood, of fire and ashes, an infinite sea of sorrow and tears" (291)), the wars, massacres, the Crusades, the Inquisition, and countless other horrors performed in God's name.

Pastor absolves himself from such a History and unambiguously lays the blame at God's door, as "no one in his right mind can possibly suggest that the Devil was, is, or ever will be responsible for so much bloodshed and death, unless some villain brings up that wicked slander accusing me of having conceived the god who will oppose this one here" (297). In an attempt to divert its flow, he makes a proposal - that God should forgive him and take him into his kingdom 
and thus eliminate evil at its source. However, God refuses, for "the Good I represent cannot exist without the Evil you represent, it is inconceivable that any God might exist without you" $(\mathrm{G}, 300)$.

Bulgakov's Satan is, like Saramago's, a positive and protective figure who, contrary to the iconoclasm of Rushdie's Satan, opposes the atheism of Berlioz and Bezdomny and even exhorts humility by punishing the two literati's arrogance to be absolutely certain about the non-existence of God. Like Rushdie's Satan, he causes an epistemological rupture by subverting the bases of knowledge - he introduces an irrational, supernatural and fantastic difference in the rationalist and atheist Soviet society. The epistemic uncertainty in turn produces an ontological one, which manifests itself in the psychological crisis of the poet Ivan Bezdomny, whose very name encodes an existential anxiety, which will be resolved by the intervention of the satanic.

The novel dramatizes the conflict between the artist and the state, between the individual and the collective, with Satan/Woland as a figure of alterity that subverts and punishes intellectual conformism and mediocrity, greed and pettiness, and ensures the triumph of love and the endurance of real art. As the epigraph, taken from the first part of Goethe's Faust, indicates, he is "part of that power which eternally wills evil and eternally works good". His message to the Master about the indestructibility of art and ideas is a message to the repressive Soviet regime and an emblem of his transgressive, unorthodox role as a champion of the repressed and the marginalized, a traditional figure of evil who, in undermining the Christian Manicheism between good and evil, serves as a reminder that there is always an alternative version to the received doxa.

A foreigner in a homogeneous and conformist society, he reveals the social rather than metaphysical aspect of evil. He is an irrational force that seems to be summoned by the entrenched rationalism and materialism of Muscovites and brings humour and laughter to a serious and sad world. Unlike in Rushdie's and Saramago's novels, Bulgakov's Satan does not rebel against and undermine God; indeed, the metaphysical world here is not divided between the forces of good and evil, but is a unified supernatural realm whose existence Woland strives to assert among the atheistic Soviet society, which is the collective antagonist of the spiritual and artistic impulses of characters such as the Master, Margarita and Bezdomny. Satan's role is even emphatically godlike in that he unifies the characters' divided and polarized selves into a unified whole.

The novel embraces a multiplicity of split personalities, or 'cripples', who as a result of the devil's appearance in Moscow are made 'whole', as they are brought to view life in its true, multilateral perspective[...] The phenomenon of split personality occurs repeatedly in Bulgakov's novel to denote a division between the characters' private and public selves and lives, between the mundane and spiritual/metaphysical aspects of their experience, and between their obligation to adhere to the dictates of the illusive 'socialist reality' and the urge to turn away from them. With immeasurable artistic ingenuity Bulgakov translates into his fiction Gershenzon's assertion that the radical intelligentsia, and the people in general, were living a split existence 'outside themselves"...]. (Pittmann 1991: 17-8) 


\section{Satanic hermeneutics: interpreting literature and culture through a satanic lens}

In Rushdie's novel, the appearance of the satanic verses effects a significant shift in the text: by identifying the contested verses as such and subsequently abrogating them from the pure essence of the divine Word, Mahound is transformed from a messenger (indeed, the Messenger) into a hermeneuticist: the separation of the satanic from the divine requires a hermeneutical ability, an ability that his later incarnations - the Imam and Ayesha, Mahound's prophetic counterparts in the other two dream sequences - carry to the extreme limits of the absolute, without any trace of a doubt. An implacable enemy of history and progress, which he sees as deviations from the Muslim religion, the Imam considers Allah's revelation to Mahound the sum of all knowledge rendering all subsequent knowledge redundant. This is profoundly ironic, taking into consideration that the authenticity of the Recitation was already subverted in the previous dream-sequence; therefore, his authority as a reliable interpreter of the Word is strongly eroded. In the Imam, we see the atrophying of the potential of the human spirit and imagination, a stubborn refusal to engage with the world, and, with that, with time, progress, change. In a progressive distanciation of religious authority, after the Prophet-founder of the religion and the officially sanctioned religious authority of the Imam-leader of an Islamic revolution, the third enlightened figure is an ordinary girl leading a hajj of villagers who is at one point even seen as a petulant child vexed at not having her way. This is the last hermeneutical level at which religious discourse is manifested, with the beautiful Ayesha transformed into a religious fanatic similar to the Imam. With this exploration of the different interpretations of a religious idea in several different scenarios, Rushdie repeats the traditional literary activation of the devil as the carrier of a satanic hermeneutics or, as Caroline Sauter states, "a modern, "deconstrutive", differential hermeneutics" (ibid, 117), opposed to the traditional, theological one, which stems from God. Similarly, Srinivas Aravamudan argues that

the slipperiness of the devil is that of the signifier itself; it is the very indeterminacy of the devil's actions that make him truly diabolical. The destinerrance of his vagrancy, his lack of address which summarizes his delinguency, the nomadic refusal to recognize the law of settlement, is an eternal escape from the transcendental signified - God. (Aravamudan 1994: 202)

The appearance of Satan, in the guise of a snake and speaking in a snake's forked language, in paradise introduces the difference of "evil" - in fact, difference as evil - into the homogeneous world created by God in which everything was "good" and faithful to its essence, presential, unequivocal and pure. Satan's evilness is to function as a contrast and an opposite of God's original, while his rhetoric problematizes God's unequivocal words by introducing double meanings, aporias, paradoxes and contradictions, as opposed to the divine and theological hermeneutics based on the truth and pure essence, identity and ethical values.

The Satanic Verses is built on this satanic aporetic elusiveness, which sees ideas, phrases, names and characters repeated and echoed in the various plotlines, which makes stabilization of meaning, and hence interpretation, nearly impossible. The 
Gospel takes the opposite approach by having God rather than the devil use an equivocating language - while Pastor unequivocally preaches fatherly care, God tricks Jesus in a covenant whose consequences he only reluctantly reveals to him. Embarking on his prophetic mission, Jesus now realizes that "what matters is not to conquer Caesar with arms, but to make God triumph with words, With words alone, Also by giving good example, and by sacrificing our lives, if necessary" (302), he tells his disciples. In a further reversal, it is he, God's emissary, who henceforward will speak enigmatically, never giving a straightforward answer but always using parables and riddles to mask the spiritual and ethical hollowness of his mission, which will make him "the shepherd who with the same crook leads to sacrifice both the innocent and the guilty, those redeemed and those lost, those born and those yet to be born, who will rid me of this remorse for I now see myself as I once saw my Father, who need only answer for twenty lives while I must answer for twenty thousand" (G, 309). Expiring on the cross and "remembering the river of blood and suffering that would flow from his side and flood the entire earth, he called out to the open sky where God could be seen smiling, Men, forgive Him, for He knows not what He has done" (341).

In The Master and Margarita, the figure of the author is central, an aspect that Rushdie also makes use of in his novel by insisting on the centrality of the satanic verses. Both Bulgakov and Rushdie figure in their texts through the authorial alter egos populating their novels in the guise of narrators, poets, scribes and writers. Rushdie undermines the monologic discourse of religion by means of both satanic and literary verses; Bulgakov also aligns his satanic Woland and his entourage with the Master against the repressive hegemony of the official institutions, thereby asserting the artistic imagination and the satanic principle as carriers of spiritual and ethical truths that are suppressed in a bureaucratic and conformist society. An indicative scene in this respect is the one in which Koroviev and Behemoth are prevented from entering Massolit (a major Moscow literary association) by a "citizeness" because they don't have the required identification card confirming they are writers, upon which Koroviev replies that Dostoevsky probably did not have one either, but is indisputably a writer.

\footnotetext{
'You're not Dostoevsky,' said the citizeness, who was getting muddled by Koroviev.

'Well, who knows, who knows,' he replied.

'Dostoevsky's dead,' said the citizeness, but somehow not very confidently.

'I protest!' Behemoth exclaimed hotly. 'Dostoevsky is immortal!'

'Your identification cards, citizens,' said the citizeness. (354)
}

What Satan's adventures in Moscow bring to light is the incompatibility between intrinsic human value and the bureaucratic, official construction of human identity, which constricts individuality into imposed molds of behavior and thinking. As Hannah Arendt points out, totalitarianism encourages conformism and extinguishes human individuality, which results in a radical loss of identity, i.e. a loss of human autonomy, conscience, morality and the ability to think for oneself. Hence, she identifies "the banality of evil" encouraged by the Nazi regime, as manifested in the psychology of Adolf Eichmann, the consummate bureaucrat and Nazi 
functionary, who managed to become one of the crucial players in the Final Solution not because he was a committed anti-Semite but simply because he followed orders and conformed to the normality imposed by the regime; in short, because, in relinquishing his individuality, he denied himself the ability to think and make moral judgments. This was most evident in his clichéd and slogan-filled speech, which was largely "empty talk"; he "repeated word for word the same stock-phrases and self-invented clichés":

The longer one listened to him, the more obvious it became that his inability to speak was closely connected with an inability to think, namely, to think from the standpoint of somebody else. No communication was possible with him, not because he lied but because he was surrounded by the most reliable of safeguards against the words and the presence of others, and hence against reality as such.

(Arendt 2006: 49)

Bulgakov's Soviet apparatchiks and mediocre writers who hold prominent positions in the institutional hierarchy, incapable of original thought and only able to produce commissioned, orthodox art, cannot accommodate a real artist like the Master who writes against the dominant ideology. Finally, the schizophrenic figure of the poet Ivan Bezdomny ('homeless'), with whom the novel begins and ends, embodies the author's ideal of intellectual homelessness and epistemic nomadism, for he overcomes his initial intellectual conformism by acquiring a more profound spiritual subjectivity through his contact with Woland/Satan, whose role in both Rushdie's and Bulgakov's novels is shown to be an unavoidable epistemic and ethical tool stimulating and even enabling artistic growth.

\section{Conclusion}

As this article has argued, Satan and the concept of the satanic, as used in literary discourse, figure as an oppositional principle that subverts socially and culturally imposed orthodoxies of any kind. Building on the etymology of the Hebrew and Greek roots of Satan's name, the analysed authors abandon the traditional representation of Satan as a principle of evil and rearticulate a differential ethical scheme whereby the satanic expresses the 'impure' and complex aspects of identity, language and knowledge. Ultimately, Bulgakov, Rushdie and Saramago, like Goethe and Marlowe before them, reinscribe the satanic as essentially an artistic or literary principle that can be used as a mighty tool against all forms of oppression, political or intellectual.

\section{References}

Aravamudan, S. (1994). 'Being God's Postman Is No Fun, Yaar': Salman Rushdie's The Satanic Verses". In Fletcher, M. D. (ed.). Reading Rushdie: Perspectives on the Fiction of Salman Rushdie, 187-208. Amsterdam - Atlanta: Rodopi.

Arendt, H. (2006.) Eichmann in Jerusalem: A Report on the Banality of Evil. London: Penguin Books. 
Bulgakov, M. (1967/2000). The Master and Margarita. Tr. Richard Pevear and Larissa Volokhonsky. London: Penguin Books.

Forsyth, N. (2003). The Satanic Epic. Princeton and Oxford: Princeton University Press.

Goethe, J. W von. (1790/2007). Faust: A Tragedy in Two Parts. Tr. John A. Williams. Ware, Hertfordshire: Wordsworth Editions Ltd.

Levy, B. W. (1995). Blasphemy: Verbal Offense against the Sacred, from Moses to Salman Rushdie. Chapel Hill and London: The University of North Carolina Press.

Marlowe, Ch. (1604/2001). Doctor Faustus. New York: Signet Classic.

Pittmann, R. H. (1991). The Writer's Divided Self in Bulgakov's The Master and Margarita. New York: Palgrave Macmillan.

Rushdie, S. (1988/1998). The Satanic Verses. London: Vintage Books.

Ruthven, M. (1991). A Satanic Affair: Salman Rushdie and the Wrath of Islam. London: The Hogarth Press.

Saramago, J. (1991/1993). The Gospel according to Jesus Christ. Tr. Giovanni Pontiero. London: The Harvill Press.

Sauter, C. (2017). The Diabolic Logic of Logos: Towards a Hermeneutics of Hell in Goethe's Faust. In Thuswaldner, G. and Russ, D. (eds.). The Hermeneutics of Hell: Visions and Representations of the Devil in World Literature, 115-142. Palgrave Macmillan, DOI 10.1007/978-3-319-52198-5_1. 